\title{
PEMBELAJARAN AL GORITMA DAN PEMOGRAMAN MENGGUNAKAN ELEARNING AL GORITMA BERBASIS WEB
}

\author{
NESSA OVIA QULSUM ( 0305203076) \\ PROGRAM STUDI PENDIDIKAN MATEMATIKA \\ UNIVERSITAS ISLAM NEGERI SUMATERA UTARA \\ Jl.William Iskandar Pasar V, Medan
}

\begin{abstract}
An algorithm is an effective method expressed as a finite series.Algorithm is also a collection of commands to solve problemsIt is necessary to do this in a systematic, structured and logical manner. When solving the algorithm itself, Various problems often arise, such as incorrect structure, algorithm This is illogical, and solves the confusion of the algorithm itself. Author's method Name it "EL-Goritma" or the abbreviation for e-learning algorithm. EL-Goritma himself is the author Includes several facilities to support future learning, such as real-time chat, video Telephone, discussion room, study money. The purpose of this method is to make it easier for students And students through getting references and solving algorithm tasks Resources from lecturers and other teachers.
\end{abstract}

Keywords : elearning, algorithm, program, programing, web, learning

\begin{abstract}
ABSTRAK
Algoritma merupakan cara yang efesien dinyatakan untuk deret hingga. Algoritma sering juga disebut sebagai kumpulan arahan untuk menetas permasalahan. Prihal ini diperlukan untuk dilakukan secara sistematis, terstruktur dan logis. Saat memecahkan algoritma itu sendiri, Berbagai masalah sering muncul, seperti struktur yang salah, algoritma Ini tidak logis, dan selesaikan kebingungan
\end{abstract}


algoritme itu sendiri. Metode penulis Beri nama "EL-Goritma" atau singkatan dari algoritma e-learning. EL-Goritma sendiri adalah penulisnya Termasuk beberapa fasilitas untuk mendukung pembelajaran di masa depan, seperti real-time chat, video Telepon, ruang diskusi, uang belajar. Tujuan dari metode ini adalah untuk memudahkan siswa Dan siswa melalui mendapatkan referensi dan menyelesaikan tugas algoritma Sumber daya dari dosen dan guru lainnya.

Kata kunci : Elearning, Algoritma, Program, Pemograman, Web, Pembelajaran

\section{PENDAHULUAN}

Kemajuan ilmu pengetahuan dan teknologi khususnya kemajuan teknologi informasi telah membawa banyak dampak positif, salah satunya kemajuan dunia pendidikan.

Pendidikan formal. Baik informal maupun informal dapat menikmati fasilitas Dalam bentuk proses pengajaranMenyediakan teknologi informasi Banyak kemudahan dan keuntungan setiap orang. Konsep ini, yang kemudian disebut e-learning, memiliki efek mengubah pendidikan tradisional ke dalam bentuk digital dalam hal konten dan sistem. Kemudahan dan manfaat dari sistem pembelajaran ini mendorong berbagai institusi pendidikan untuk menggunakan sistem e-learning untuk meningkatkan efektifitas dan fleksibilitas pembelajaran. Guru dapat memberikan ujian atau latihan online kepada pengguna Dalam hal ini adalah sistem mahasiswa atau mahasiswa. Ujian online dapat memudahkan guru untuk mengevaluasi siswa dan memahami kemajuan siswa

Algoritma merupakan tata cara efisien yangdiekspresikan selaku rangkaian terbatas.Algoritma pula ialah kumpulan perintahbuat menuntaskan sesuatu permasalahan. Perintah-perintah ini bisa diterjemahkan secara bertahapdari dini sampai akhir. Permasalahan tersebut dapatberbentuk apa saja, dengan ketentuan buat setiapkasus mempunyai 
kriteria keadaan dini yangwajib

dipadati saat sebelum melaksanakan

sebuah algoritma. Algoritma pula

mempunyai pengulanganproses

(iterasi), serta pula mempunyai

keputusansampai keputusan berakhir.

Dalam cabang disiplin ini, algoritma dipelajarisecara abstrak, terlepas dari system komputerataupun bahasa pemrograman yang

dipergunakan.Algoritma yang berbeda bisa diterapkan untuksesuatu kasus dengan kriteria yang sama.Kompleksitas dari sesuatu algoritma merupakandimensi seberapa banyak komputasi yangditerapkan pada algoritma tersebut untuk menuntaskanpermasalahannya. Secarainformal, algoritma yang bisa menyelesaikan kasus dalam waktu yang relative singkat mempunyai tingkatan kompleksitas yang rendah, sedangkan buat algoritma yang menyelesaikankasus dalam waktu yang lebih lamamempunyai tingkatan kompleksitas yang lebih tinggipula.

Dalam mata kuliah logika serta algoritma, kitasudah menekuni tentang algoritma danpelaksanaannya dalam pemrograman computer. Kesusahan yang dialami dalam kasus inimerupakan susahnya kita paham algoritma danpenyelesaian dari kasus yang dialami,dan sulitnya membayangkan struktur informasi yanghendak digunakan. Dalam menguasai penyelesaiansesuatu kasus, kita hendak lebih gampang buat mengingat serta memahaminya apabilakasus itu bisa ditampilkan dalam bentukvisual serta foto, sehingga penyajian nyajadi lebih menarik.Dari kasus diatas, penulis inginmenolong memudahkan penyelesaianalgoritma buat memudahkan penyelesaian matematika dengan membuat fitur lunakperlengkapan bantu logika serta algoritma

\section{Hakikat E- Learning}

E- learning merupakan sesuatu sistem ataupun konseppembelajaran yang menggunakan teknologidata dalam proses belajar mengajar. Berikut sebagian penafsiran e- learning dari berbagaisumber. Pendidikan yang 
disusun dengan tujuan memakai sistem elektronik atau pc sehingga sanggup menunjang proses pendidikan.Proses pendidikan jarak jauh denganmencampurkan prinsip- prinsip dalam proses pendidikan dengan teknologi (chandrawati, 2010).

Sistem pendidikan yang digunakan selaku fasilitas buat proses belajar mengajaryang dilaksanakan tanpa wajib bertatap muka secara langsung antara guru dengan siswa( ardiansyah, 2013)Bagi Rosenberg( 2001) ciri e- learning bertabiat jaringan, yang membuatnya sanggup membetulkan secara kilat, menyimpanataupun menimbulkan kembali, mendistribusikan,serta sharing pendidikan serta data.Ciri elearning bagi nursalam ( 2008: 135) merupakan:

1. Menggunakan jasa teknologi elektronik.

2. Menggunakan keunggulan pc (digitalmedia serta pc networks)

3. Menggunakan bahan ajar mandiri (self-study material) dan meletakkannya di komputer agar dosen dan mahasiswa dapat mengaksesnya kapan saja, di mana saja.

4. Anda dapat melihat penggunaan rencana pendidikan, pengaturan kursus, hasil kemajuan pembelajaran, dan hal-hal terkait manajemen pembelajaran kapan saja di PC

Khasiat E- Learning Ada pula sebagian khasiat pemakaian elearningadalah:

1. Fleksibel. E- learning berikan fleksibilitasdalam memilah waktu serta tempat untukmengakses ekspedisi.

2. Belajar mandiri. E- learning memberipeluang untuk pembelajar secara mandirimemegang kendali atas keberhasilan belajar.

3. Efisiensi bayaran. E- learning berikan efisiensi bayaran untuk administrasi penyelenggara,efisiensi penyediaan fasilitas serta sarana fisik buat belajar serta efisiensi bayaran bagipembelajar merupakanbayaran transportasi dana komodasi. 
Manfaat e- learning bagi

pranoto, $\operatorname{dkk}(2009: 309)$ merupakan:

1. Pemakaian e- learning buat menunjangpenerapan proses belajar dapattingkatkan energi serap mahasiswa atasmodul yang diajarkan.

2. Tingkatkan partisipasi aktif darimahasiswa.

3. Tingkatkan partisipasi aktif darimahasiswa.

4. Tingkatkan keahlian belajar mandirimahasiswa.

5. Tingkatkan mutu modul pendidik danpelatihan.

6. Tingkatkan keahlian menampilkandata dengan fitur teknologi data, dimana dengan fitur bisaasusah dicoba

Globalisasi yang memegang seluruh sisi kehidupandikala ini menuntut manusia wajib berkompetisi diberbagai zona kehidupan. Apabila tidak mampu bersaing, hingga dengan sendirinya hendak tersingkir daripercaturan kehidupan

global. Salah satunya

denganterwujudkan Revolusi Industri. secara formal lahirdi Jerman pada dikala diadakan Hannover Fair padatahun 2011(Kagermann, etal, 2011) hingga perlu usaha besar mempersiapkan tantang tersebut(Zhou,et angkatan laut(AL), 2015). Menyikapi perihal ini, suatu kurikulumyang diharapkan sanggup mengestimasi kebutuhanpara lulusan dengan lapangan pekerjaan yang menanti di depan mata. Salah satu bidang manajemeninformatika. Jurusan ini wajib mempunyai kompetensiataupun skill lulusan setara dengan capain pendidikan pada rumpun ilmu informatika serta pc ialah:sanggup mengenali spesialisai perancangan dan pengembangan aplikasi buat sistem data atauweb, programmer ataupun website 
programmer,merancang e-

business serta administrasi

database( Aptikom, 2016).

Pemrograman telah

menjadi keterampilan dan

merupakan kekuatan strategis

pada abat ke-21 dengan semua

kegiatannya sudah dikelilingi

oleh perangkat program, seperti

cell phone, tablet, $\mathrm{PC}$, dan

teknologi yang digunakan

dalam kehidupan sehari- hari.

Namun, belajar pemrograman

dan pengembangannya tidaklah

mudah, bahkan dengan

berbagai variasi jenis bahasa

pemrograman yang banyak

digunakan (Areias, et al,

2007)(Tan, et al, 2009) belum

tentu mampu menjadi software

engineer yang handal. Menjadi

seorang ahli software engineer

membutuhkan waktu 10 tahun

(Winslow, 1996). Seorang

siswa yang baru mulai belajar

bahasa pemrograman akan

menghadapi banyak kesulitan

dalam keterampilan

pemrograman. Jadi, sebelum memahami bahasa

pemrograman, mahasiswa

harus terlebih dahulu

memahami konsep dan sintaks

bahasa pemrograman dengan

mengembangkan masalah dan

kemampuan algoritmik (Tan, et

al, 2009). Rsoy, et al, 2006)

(McGill, 1997).

Belajar Algoritma dan

Pemrograman adalah mata

kuliah dasar yang harus

dikuasai oleh setiap

mahasiswa, dimana mahasiswa

dapat memahami algoritma

dengan menganalisis logika

dasar dan kemudian

berpengaruh terhadap

penyerapan materi

pembelajaran pemrograman

(Jenkins, 2002)(Lahtinen,

2006)(Roebling,

2010)(Tuparov, etal, 2014).

Algoritma adalah sistim

kerja komputer memiliki

brainware, equipment, dan

programming. Tanpa salah satu

dari ketiga sistim ini komputer 
tidak akan berguna. Kita akan

lebih fokus pada

softwareckomputer.

Programming terbangun atas

susunan program) dan

language structure (cara

penulisan/pembuatan program).

Untuk menyusun program atau

language structure,

diperlukannya langkah-

langkah yang sistematis dan

logis untuk dapat

menyelesaikan masalah atau

tujuan dalam compositions

pembuatan suatu programming.

Maka, algoritma berperan

penting dalam penyusunan

program atau language

structure tersebut.

\section{Pengertian algoritma}

adalah suatu susunan yang

logis dan sistematis untuk

memecahkan suatu masalah

atau mencapai suatu tujuan

tertentu. Dalam dunia

komputer, algoritma sangat

berperan penting dalam

pembangunan suatu programming. Dalam dunia

sehari-hari, kita mungkin

bahkan tidak mengetahuinya,

tetapi algoritma telah

memasuki kehidupan kita.

Algoritma lain

logaritma. Logaritma adalah

kebalikan dari pangkat atau

pangkat Contoh logaritma

seperti $b c=a$ ditulis sebagai

blog $\mathrm{a}=\mathrm{c}$ ( $\mathrm{b}$ disebut premis)..

Algoritma adalah

menemukan lever keahlian

komputer atau informatika.

Banyak ranting keahlian

komputer yang diacu bagian

dalam vokabuler algoritma.

Namun jangan berpikiran

algoritma selalu identik tambah

keahlian komputer saja. Cara

menyelenggarakan makanan

kecil atau buatan yang

dinyatakan bagian dalam

ramuan buatan, itu juga

menemukan algoritma. Ibu-

permulaan yang mencari akal

ramuan buatan tertulis akan

mempersembahkan tunggal 
persatu praktik pembuatannya, lepas mengamalkan kiat (mengerjakan aksi) sesuai yang ia baca. Secara umum, sudut yang mengamalkan kiat disebut pemroses (processor).

Pemroses bisa berwarna manusia, komputer, robot, perlengkapan mekanik, perlengkapan elektronik dll. Melaksanakan algoritma berisi mengamalkan praktik-praktik yang tertera bagian dalam algoritma tertulis.Untuk algoritma yang akan diimplementasikan di komputer, algoritma harus diubah ke notasi bahasa pemrograman sehingga disebut program. Oleh karena itu, program merupakan realisasi atau implementasi dari algoritma. Program ditulis dalam salah satu bahasa pemrograman. Kegiatan menulis program disebut pemrograman (programming).
Orang yang menulis program disebut programmer. Setiap langkah dalam program disebut instruksi atau instruksi. Jadi program adalah: "Sebuah urutan logis dan sistematis dari instruksi yang menggunakan sintaks tertentu untuk memecahkan masalah."

Secara umum, sebuah komputer terdiri dari 4 komponen utama, yaitu:

- Perangkat input pertama (perangkat input)

- Perangkat keluaran kedua (perangkat keluaran)

- Unit Pemrosesan Sentral (Central Processing Unit)

- Memori (memori penyangga)

Pengoperasian keempat komponen tersebut dapat dijelaskan sebagai berikut:

- Program dimasukkan ke dalam memori komputer. 
- Semua instruksi dalam memori dikirim ke CPU untuk dieksekusi.

- $\quad$ CPU menjalankan operasi sesuai dengan instruksi.

- Jika operasi membutuhkan data, data dibaca dari perangkat input. Data masukan disimpan dalam memori dan kemudian dikirim ke CPU untuk operasi yang memerlukan operasi sebelumnya.

- Ketika proses menghasilkan output atau informasi, output disimpan dalam memori kemudian memori menulis output ke perangkat

\section{STUDI LITERATUR}

Studi literatur yang digunakan adalah pengumpulan bahan bahan referensi mengenai pembelajaran algoritma dan pemograman dengan mengunjungi beberapa jurnal, artikel, dan beberapa buku yang berkaitan dengan pembelajaran algoritma dan pemograman, dalam mempelajari literatur dulakukan tinjauan pustaka yang mendalam untuk memahami pembelajaran dasar algoritma dan pemograman.

\section{METODE}

Peralatan dan bahan penelitian yang di pakai dalam penelitian ini merupakankunjungan ke berbagai jenis jurnal. Selain jurnal panduan tambahan untuk penelitian ini, ada juga buku “ ALGORITMA DAN PEMOGRAMAN " yang ditulis oleh Bapak Edy budirahman .Buku "Pengantar Algoritma dan Pemrograman " yang ditulis oleh Alex Budiyanto dan berbagai jenis jurnal artikel dan modul bacaan lainnya. Dalam pemilihan teknologi artikel dan sumber artikel, filter sesuai topik yang akan penulis bahas yaitu Algoritma 
pemograman.Setelah

menganalisa dan memahami isi

bacaan dari masing-masing

artiket terkait barulah penulis

membuat suatu penyaringan

(apply filter). Setelah

penyaringan, penulis akan

merumuskan kondisi untuk

setiap judul artikel dengan

kata-kata dan algoritma dan

prmograman . Penulis telah

memperoleh dua artikel yang

dapat disebutkan dalam ulasan

ini .

\section{PEMBAHASAN}

EL-Gorithm ini dibuat

berdasarkan kurangnya

referensi nyata untuk algoritma

itu sendiri. Selama ini beberapa

pemula mengalami kesulitan

pada tahap awal pembuatan

algoritma, pengetahuan dasar

pemecahan masalah dan

aturan-aturan yang harus ada

dalam algoritma itu sendiri.

Alat ini nantinya akan diberi

nama "EL-Goritma" Oleh

karena itu penulis membahas beberapa hal dan metode yang

dapat mempermudah pemula

untuk menggunakan buku

berbasis html atau web atau

android.

Metode Pembuatan Alat

Metode pembuatan

yang dilakukan ialah dengan

menggunakan coding berbasis

html, php, dan jika

dimungkinkan akan

dipermudah dengan

mengaitkannya dengan

database. Beberapa pandangan

EL-Goritma penulis

menggunakan beberapa

template gratis yang tersedia di

Internet. Alasan menggunakan

template adalah untuk

memudahkan penulis

menyelesaikan EL-Goritma

tepat waktu, sedangkan untuk

database, penulis bermaksud

untuk meningkatkan kinerja

atau informasi yang berkaitan

dengan algoritma itu sendiri.

Publikasikan dan publikasikan

di dunia maya dengan 
memberikan layanan input

informasi.

\section{Tahapan-Tahapan}

\section{Pembuatan}

1. Alat

Alat yang akan penulis gunakan untuk membuat

“algoritma e-learning” adalah laptop dan perlengkapannya

2. Bahan

- Aplikasi coding html (sublime)

- Web browsing

- Template

- Refrensi materi

- Free hosting

3. Proses kerja

Proses kerja penulis selanjutnya adalah bekerja sama untuk mendapatkan hasil yang sesuai dengan harapan penulis. Adapun untuk menambah wawasan tentang apa yang penulis tidak ketahui, penulis akan bertanya kepada orang-orang yang mampu di bidangnya masingmasing.
4. Tampilan EL-Goritma Adapun dari beberapa tahapan yang telah dilalui produsen, dapat diperoleh gambaran awal yang belum fix pada desain EL-Goritma. Tampilan dapat diubah sewaktu-waktu sesuai kebutuhan

\section{Tampilan Form Login}

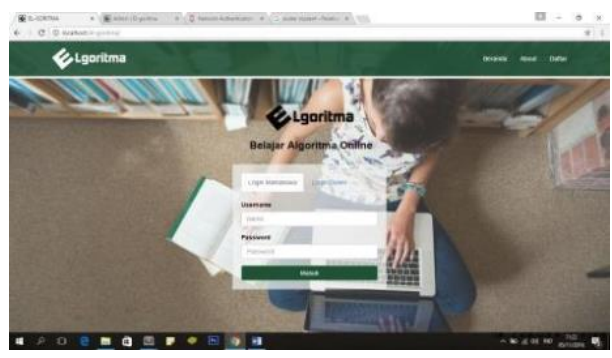

Tampilan Penjelasan

\section{Algoritma}

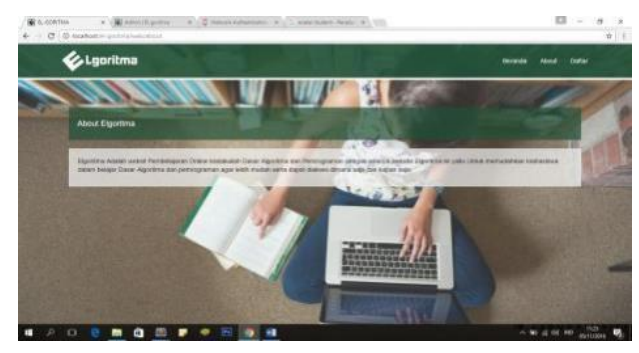


Tampilan Form Register

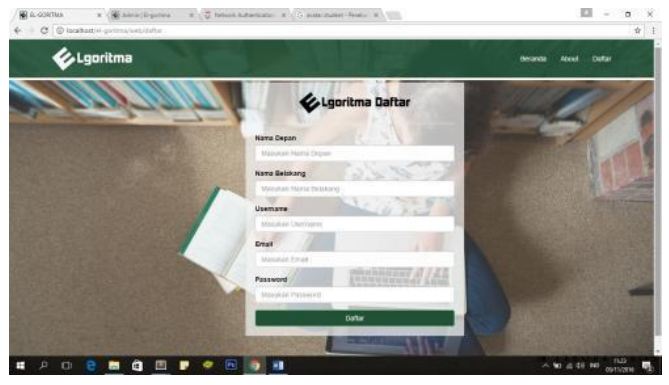

Tampilan Dashborad admin

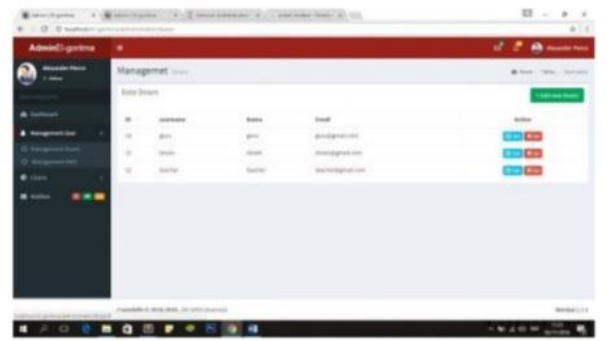

Halaman Student ( materi)

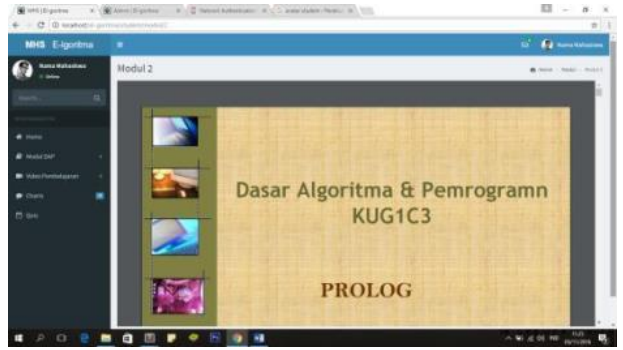

Form Ipload Materi Dosen

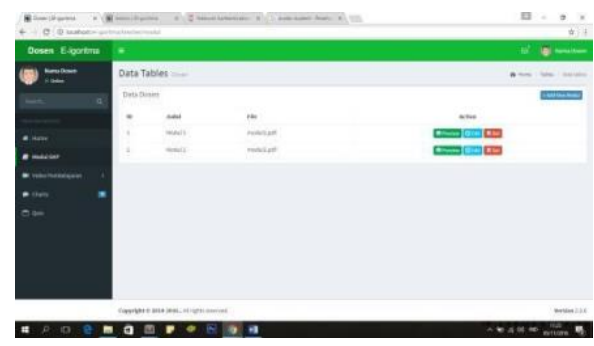

isi EL-Goritma adalah sebagai berikut:

- Header

Header berfungsi sebagai

tampilan atau judul EL-

Goritma.

- Halaman materi

Halaman materi berisi konten

materi yang akan ditampilkan.

Isi bahan ajar hanya dapat

dimasuki melalui portal dosen

kasus. Dan siswa hanya bisa

melihat dari isi materi.

- Submenu Isi

dari submenu tersebut adalah

beberapa menu yang

berhubungan dengan bagian

EL-Goritma. Submenu

tersebut nantinya akan diisi

berupa papan buletin, halaman

kuis, dll.

- Obrolan langsung

Salah satu fasilitas yang

disediakan adalah fasilitas

untuk mengobrol dengan

dosen atau dosen. Nantinya

fasilitas ini akan lebih banyak

mengobrol. Maksud dari

multi-person chat adalah chat 
room akan berisi banyak

orang, tetapi hanya satu dosen

yang menjadi pembicara

utama

- Akun

Untuk mengakses EL-

Goritma, pengguna harus

terlebih dahulu mendaftarkan

diri. Pendaftaran dibagi

menjadi dua, yaitu portal guru

dan portal siswa. Portal guru

merupakan tim pengajar yang

memberikan akses berupa

bahan masukan, kuis, dan

pengumuman. Portal siswa

terbatas untuk akses dan

jawaban, sedangkan untuk isi

EL-Goritma sendiri akan

disesuaikan dengan kebutuhan

dan akan dikembangkan

kedepannya jika diperlukan

Penciptaan algoritma EL ini

didasarkan pada kurangnya

referensi nyata dari algoritma

itu sendiri. Sejauh ini,

beberapa pemula mengalami

kesulitan pada tahap awal

pembuatan algoritma, dan dasar-dasar pemecahannya

masalah, serta aturan-aturan

yang tentunya ada didalam

algoritma itu sendiri. Alat ini

nantinya akan beri nama "EL-

Goritma”. Oleh karena itu,

penulis membahas beberapa

hal dan metode yang dapat

memudahkan pemula untuk

menggunakan buku berbasis

html atau web atau android

Alasan menggunakan

template adalah untuk

memudahkan penulis

menyelesaikan EL-Goritma

tepat waktu. Basis data yang

penulis maksud adalah untuk

meningkatkan kinerja atau

informasi yang berkaitan

dengan algoritma itu sendiri.

Publikasikan dan publikasikan

di dunia maya dengan

memberikan layanan input

informasi.

Algoritma adalah

sistem komputer, ia memiliki

Perangkat keras, perangkat

keras dan perangkat lunak. 
Tidak ada kesalahan Salah satu dari tiga sistem, komputer Ini akan sangat berguna. Kami akan lebih memperhatikan perangkat lunak komputer. Perangkat lunak didasarkan pada struktur program) dan tata bahasa (cara menulis/program). Menulis Prosedur atau tata bahasa, langkah-langkah yang diperlukan untuk mendapatkan langkah yang sistematis dan logis Masalah atau tujuan dalam proses pemecahan Membuat perangkat lunak.

$$
\text { Nah, algoritma }
$$

memainkan peran penting dalam pemrograman atau tata bahasa. Definisi algoritma adalah pengaturan Logika dan pendekatan sistematis untuk pemecahan masalah Masalah atau pencapaian tujuan tertentu.

Dalam dunia komputer, algoritma memainkan peran yang sangat penting, Sangat penting dalam pengembangan perangkat lunak. Dalam kehidupan sehari-hari, mungkin tanpa kita Sadarilah bahwa algoritma telah memasuki kehidupan kita

Struktur dasar dari algoritma tersebut adalah Semacam Sekuensia, Dalam struktur urutan ini langkahlangkahny dijalankan dalam algoritma yang diproses secara otomatis Pada gilirannya. Dari pertama, kedua,dan masih banyak lagi. Pada dasarnya sebuah programMemang dariStrukturnya dasarnya seperti ini.

Struktur pilihan, Struktur pemilihan ini untuk menentukan pilihan langkah , Hal ini didasarkan pada kondisi atau Membuat sebuah keputusan. Struktur iniSelalu tandai dalam bentuk diagram alur keputusan(Diagram aliran berlian).Banyak contoh yang bisa kita terapkan Ketika sampai pada pengambilan keputusan, jenis struktur 
ini,Termasuk: sesuai dengan

diskon yang berbedaJumlah

barang yang akan dibeli.

Struktur melingkar, struktur

ini memberikan perintah atau

tindakan yang dieksekusi

beberapa kali. Misalnya Jika

teman ingin menulis kata

"belajar c" sepuluh kali. Akan

lebih efisien jika itu terjadi

Teman menggunakan struktur

ini sebagai gantiTulis dalam

satu baris sepuluh kali

E-learning adalah sebuah

sistem atau konsepPendidikan

TeknikInformasi dalam proses

belajar mengajar.

mengikutiBeberapa

pemahaman tentang elearning

sumber. Struktur kursus

danTujuan penggunaan sistem

elektronik atauKomputer

sehingga dapat mendukung

proses Mempelajari. roses

pembelajaran jarak jauh

menggabungkan prinsip dan

teknologi ke dalam proses

pembelajaran. Sistem pembelajaran yang digunakan

Sebagai sarana proses

pengajaran Tidak perlu

bertatap muka Langsung antara

guru dan murid

(ardiansyah,2013) Menurut

karakteristik Rosenberg (2001),

e-Pembelajaran berjejaring,

yang membuatnyaMampu

memperbaiki dengan cepat dan

menghematAtau menyalin,

mendistribusikan,Dan berbagi

pembelajaran dan informasi.

Sesuai dengan fitur e-

learning Nursalam(2008:135)

adalah:Semacam.

Memanfaatkan layanan

teknologi

elektronik.Manfaatkan

komputer (digital) media dan

jaringan komputer)

Beberapa manfaat

menggunakan e-learning

adalah:

- Semacam. fleksibel. E-

learning memberikan

keleluasaan untuk memilih 
kapan dan dimana harus

dikunjungi.

- Institut Teluk bersifat

independen. pemberian e-

learning Peserta didik

memiliki kesempatan untuk

secara mandiri mengontrol

keberhasilan belajar $\mathrm{c}$.

Efektivitas biaya. E-learning

meningkatkan efisiensibiaya

administrasi penyelenggara.

Pranoto, dkk (2009:309)

berpendapat bahwa manfaat $\mathrm{e}$

learning adalah:

- Penggunaan e-learning untuk mendukung pelaksanaan proses pembelajaran dapat meningkatkan daya serap siswa terhadap materi yang diajarkan.

- Meningkatkan partisipasi aktif siswa

- Meningkatkan partisipasi aktif siswa. Meningkatkan kemampuan belajar mandiri siswa.

- Meningkatkan kualitas bahan ajar dan pelatihan, Tingkatkan kemampuan tampilan

informasi.

\section{KESIMPULAN}

Tulis program atau tata bahasa untuk mendapatkan langkah-langkah yang diperlukan sistem dan langkahlangkah logika untuk memecahkan masalah atau tujuan dalam proses pembuatan perangkat lunak. Nah, algoritma memainkan peran penting dalam pemrograman atau tata bahasa. Dalam dunia komputer, algoritma memainkan peran yang sangat penting, Sangat penting dalam pengembangan perangkat lunak. Struktur dasar dari algoritma tersebut adalah Semacam Sekuensia, Dalam struktur urutan ini langkahlangkahny dijalankan dalam algoritma yang diproses secara otomatis Pada gilirannya.

Struktur iniSelalu tandai dalam bentuk diagram alur 
keputusan. E-learning adalah

sebuah sistem atau

konsepPendidikan

TeknikInformasi dalam proses

belajar mengajar. Proses

pembelajaran jarak jauh

Memasukkan prinsip dalam

proses Belajar dengan

teknologi . Sistem

pembelajaran yang digunakan

Sebagai sarana proses

pengajaran Tidak perlu

bertatap muka Langsung antara

guru dan murid Menurut

karakteristik Rosenberg, e-

Pembelajaran berjejaring, yang

membuatnyaMampu

memperbaiki dengan cepat dan

menghematAtau

menyalin, mendistribusikan,

dan berbagi pembelajaran dan

informasi

Untuk mengakses EL-

Goritma, pengguna harus

terlebih dahulu mendaftarkan

diri. Pendaftaran dibagi

menjadi dua, yaitu portal guru

dan portal siswa. Portal guru merupakan tim pengajar yang

memberikan akses berupa

bahan masukan, kuis, dan

pengumuman Portal mahasiswa

membatasi akses dan jawaban,

sedangkan isi EL-Goritma

sendiri akan disesuaikan

dengan kebutuhan dan

dikembangkan saat dibutuhkan

di masa mendatang. Pembuatan

algoritma EL ini didasarkan

pada kekurangan dari algoritma

itu sendiri. Selama ini beberapa

pemula mengalami kesulitan

dalam tahap awal merumuskan

algoritma, pengetahuan dasar

pemecahan masalah, dan

aturan-aturan yang harus ada

dalam algoritma itu sendiri.

Alat tersebut nantinya akan

diberi nama "EL-Goritma".

Oleh karena itu, penulis

membahas beberapa hal dan

metode yang dapat

memudahkan pemula untuk

menggunakan buku berbasis

html atau web atau android. 
EL-Gorithm ini dibuat

berdasarkan kurangnya

referensi nyata untuk algoritma

itu sendiri. Selama ini beberapa

pemula mengalami kesulitan

pada tahap awal pembuatan

algoritma, pengetahuan dasar

pemecahan masalah dan

aturan-aturan yang harus ada

dalam algoritma itu sendiri.
Alat ini nantinya akan diberi

nama "EL-Goritma" Oleh

karena itu penulis membahas

beberapa hal dan metode yang

dapat mempermudah pemula

untuk menggunakan buku

berbasis html atau web atau

android. 


\section{DAFTAR PUSTAKA}

Ardiansyah, Ivan. 2013. Eksplorasi Pola Komunikasi dalam Diskusi Menggunakan Moddle pada Perkuliahan Simulasi Pembelajaran Kimia. Bandung: Universitas Pendidikan Indonesia.

Budiman,Edi.2015.Belajar Dasar Algoritma Dan Pemograman.Samarinda: pemula

Chandrawati, Sri Rahayu. 2010. Pemanfaatan E-learning dalam Pembelajaran. No 2 Vol. 8 .

Nursalam dan Ferry Efendi. 2008. Pendidikan dalam Keperawatan. Jakarta: Salemba Medika.

Pranoto, alvini.dkk. 2009. Sains dan teknologi. Jakarta: pt gramedia pustaka utama. Pendit, Putu Laxman, dkk. 2007. Perpustakaan Digital: Perspektif Perpustakaan Perguruan Tinggi Indonesia. Jakarta: Sagung Seto.

Qolyubi, dkk. 2007. Dasar-dasar Ilmu Perpustakaan dan Informasi. Yogyakarta: Jurusan Ilmu Perpustakaan dan Informasi Fakultas Adab UIN Sunan Kalijaga

Supriyanto, Wahyu dan Ahmad Muhsin. 2008. Teknologi Informasi Perpustakaan. Yogyakarta: Kanisius.

Suteja, Bernard Renaldy. 2008. Memasuki Dunia e-Learning. Bandung: Informatika. Yuana, Rosihan Ari. 2007. Membangun Aplikasi E-Learning Berbasis Web dengan PHP dan MYSL. Surakarta: Sebelas Maret University Press. 